\title{
Simulasi Molecular Dynamic (MD) Senyawa Analog Kalkon Sebagai Inhibitor Untuk Sel Kanker Paru A549
}

\author{
Neni Frimayanti $^{1^{*}}$, Rahma Dona ${ }^{1}$, Felly Cahyana ${ }^{1}$ \\ ${ }^{1}$ Sekolah Tinggi Ilmu Farmasi Riau; Jalan Kamboja, Simpang Baru Panam, 28292 \\ e-mail: nenifrimayanti@gmail.com
}

\begin{abstract}
ABSTRAK
Kalkon merupakan senyawa yang berasal dari alam dengan beberapa golongan senyawa kalkon sudah terbukti memiliki aktivitas sebagai antikanker. Penelitian ini bertujuan untuk mengetahui kestabilan senyawa analog kalkon yang telah di-docking sebagai inhibitor bagi kanker paru A549. Penelitian ini menggunakan 3 senyawa analog kalkon yang diperoleh dari penelitian sebelumnya dengan menggunakan gefitinib sebagai kontrol positifnya. Studi simulasi molecular dynamic ini dilakukan menggunakan komputer dengan software MOE 2007.09. Data hasil simulasi berupa nilai energi konformasi (kcal/mol), ikatan hidrogen, dan kesamaan asam amino yang menunjukkan kestabilan interaksi ligan senyawa kalkon terhadap asam amino pada reseptor. Hasil molecular dynamic menunjukkan bahwa dari 3 senyawa yang disimulasikan senyawa 5 adalah yang paling stabil karena memiliki nilai energi konformasi yang rendah yaitu $-4.050,14 \mathrm{kcal} / \mathrm{mol}$ dan terdapat dua asam amino yang membentuk ikatan hidrogen dengan sisi aktif reseptor yaitu Arg655 dan Tyr100, serta memiliki 6 residu asam amino yang sama dengan hasil docking.
\end{abstract}

Keywords: Turunan kalkon, Molecular dynamic, anti-kanker paru A549

\begin{abstract}
Chalcone is a natural compound with several groups of chalcone compounds have been shown to have anticancer activity. The aim of this study is to check the stability of chalcone analogue which has been docked into A549 lung cancer. This study used 3 chalcone analogue compounds obtained from previous studies using gefitinib as a positive control. The molecular dynamics simulation study was carried using computer with MOE 2007.09 software. The results of data simulation are conformation energy value (kcal/mol), hydrogen bonds, which amino acid bonds, it is shown the stability of ligand interaction between amino acids at the receptor. The molecular dynamic results shown that from 3 compounds, compound 5 is the most stable because it has a low conformation energy value of $-4.050,14 \mathrm{kcal} / \mathrm{mol}$ and two formed amino acids with hydrogen bonds like Arg65 and Tyr100, and it is also have the same amino 6 residues acids with the docking results.
\end{abstract}

Keywords: Chalcone derivatives,Molecular dynamics, A549 cell anti-cancer

\section{PENDAHULUAN}

Kanker merupakan istilah umum yang digunakan untuk menggambarkan sel-sel yang terlepas dari sistem pengawasan pertumbuhan dan reproduksi tubuh. Pertumbuhan yang tidak terkontrol akan menyebabkan sel tumbuh berkembang menjadi tumor yang dapat menyebar dan berkembang di bagian lain dalam tubuh (Klamerus et al, 2011). Berdasarkan data International Agency for Research on Cancer (IARC), bahwa pada tahun 2012 terdapat 14 juta kasus baru kanker dan juga 8 juta kematian akibat kanker di seluruh dunia. Kanker paru, hati, perut, kolorektal, dan kanker payudara adalah penyebab terbesar kematian setiap tahunnya (Anonim, 2015).

Sekitar $70 \%$ kematian kanker paru-paru disebabkan oleh merokok, meskipun di negara maju penggunaan tembakau telah menurun namun di negara berkembang prevalensi merokok masih tetap tinggi (Jusuf et al, 2015). Di Indonesia, kanker paru menyebabkan kematian utama pada laki-laki $(21,8 \%)$ dan kematian kedua $(9,1 \%)$ kanker pada perempuan setelah kanker payudara $(21,4 \%)$ (Anonim,2017)
Berbagai usaha telah dilakukan dalam terapi kanker paru seperti kemoterapi, radiasi, pembedahan. Pengobatan kanker menggunakan kemoterapi akan menimbulkan efek samping berupa kerontokan rambut, mual, muntah, diare, rentan terinfeksi, trombositopenia, neuropati, dan myalgia sedangkan radiasi menyebabkan efek rasa mual muntah, dan pembedahan tidak seluruhnya mampu mengangkat jaringan tubuh yang rusak karena kanker (Dipiro et al, 2015). Karena hal tersebut perlu usaha untuk pencarian zat yang berpotensi sebagai inhibitor kanker paru yang baru sangat diperlukan untuk memaksimalkan efektivitas dan meminimalkan toksisitasnya. Salah satu senyawa yang menarik untuk diteliti adalah kalkon karena sifat farmakologisnya dan turunan sintetisnya memiliki aktivitas sitotoksik yang signifikan terhadap berbagai kanker (Pingaew et al, 2014).

Penelitian dengan menerapkan teknik komputasi dapat membantu untuk mencari turunan kalkon yang berpotensi sebagai agen aktif baru melawan kanker sebelum dilakukan eksperimen laboratorium. Teknik yang umum digunakan adalah menggunakan metode in silico yaitu molecular docking dan molecular dynamic (MD). Metode molecular docking digunakan untuk memprediksi 
aktivitas dari senyawa-senyawa seperti kalkon dengan menghitung energi bebas ikatan atau afinitas yang terlibat dalam interaksinya dengan sisi aktif protein. Sedangkan molecular dynamic dilakukan untuk mengevaluasi hasil proses moleculer docking.

Penelitian Khusnah (2018) dari 10 senyawa analog kalkon dilaporkan 3 senyawa analog kalkon yang berpotensi sebagai inhibitor kanker paru A549 dengan menggunakan metode molecular docking yang dilihat dari nilai energi bebas ikatan yaitu senyawa (2) atau 1-(2aminophenyl)-3-phenylprop- 2-en-1-one, senyawa (5) 3(benzo[d][1,3]dioxol-5-yl)-1-(2-hydroxyphenyl)prop-2en-1-one dan senyawa (6) 1,3-bis(2-hydroxyphenyl)prop2-en-1- one yang memiliki nilai energi bebas ikatan berturut-turut $-7,2 \mathrm{kcal} / \mathrm{mol},-6,9 \mathrm{kcal} / \mathrm{mol}$, dan $-6,9$ $\mathrm{kcal} / \mathrm{mol}$.

Dengan Kelebihan metode molecular dynamic diantaranya dapat menekan biaya dan waktu yang diperlukan dalam proses penemuan kandidat molekul obat. Selain itu untuk memprediksi aktivitas senyawa analog kalkon sebelum dilakukan eksperimen di laboratorium. Berdasarkan hal di atas maka dilakukan penelitian molecular dynamic terhadap beberapa senyawa analog kalkon yang memiliki nilai konformasi rendah dan berpotensi aktif sebagai inhibitor kanker paru A549

\section{METODE PENELITIAN}

\section{Alat}

Penelitian ini menggunakan seperangkat komputer Vaio Intel(R) Core(TM) i3-3271 CPU, 1,80 GHz, dengan RAM 2 GB, Windows 10. Program yang digunakan adalah Chemdraw Ultra 12.0 (CambridgeSoft), software MOE 2007.09 program MOE (Chemical Computing Group Inc).

\section{Bahan}

Pada penelitian ini bahan yang digunakan adalah 3 senyawa analog kalkon (kompleks) hasil docking yang telah diteliti oleh Khusnah (2018) dalam format pdb dan gefitinib sebagai kontrol yang ditunjukkan pada Tabel 1.

\section{Preparasi File Simulasi Molecular Dynamic}

Preparasi file simulasi molecular dynamic dilakukan optimasi geometri dan minimisasi energi pada kompleks dengan menggunakan software MOE 2007.09. Optimasi geometri dilakukan pada kompleks dengan memilih opsi partical charge dengan parameter method yang digunakan adalah current forcefield. Selanjutnya dilakukan minimisasi energi dengan memilih opsi energy minimize dengan parameter forcefield CHARMM27, solvasi yang digunakan adalah born dan RMS gradien 0,01 . Parameter lainnya sesuai default dan file output dalam format $\mathrm{mdb}$.
Tabel 1. Struktur Senyawa Analog Kalkon Sebagai Ligan

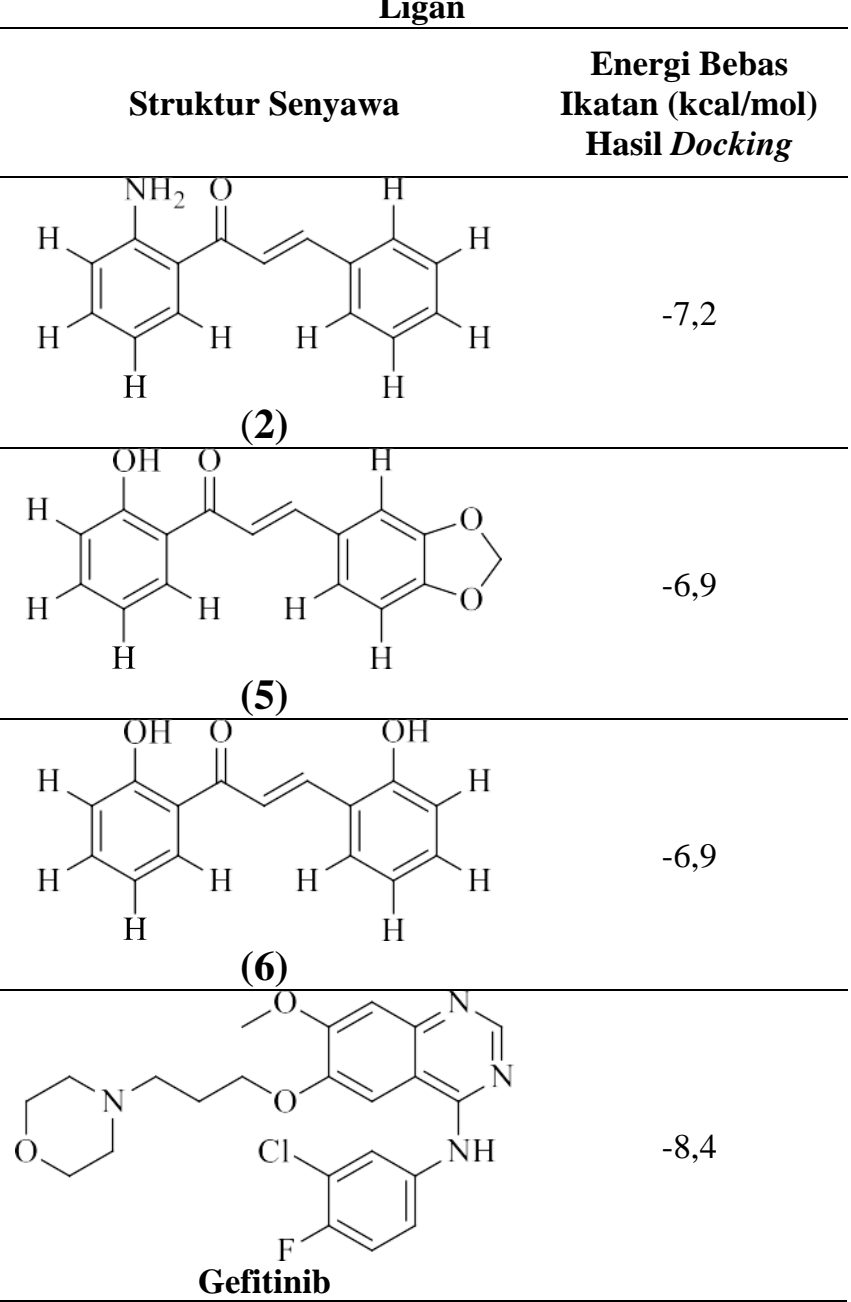

\section{Simulasi Molecular Dynamic}

Parameter yang digunakan sesuai dengan default pada MOE, yaitu ensemble NVT $(\mathrm{N}$ : jumlah atom, V: volume, $\mathrm{T}$ : temperatur) dengan algoritma NPA. Simulasi molecular dynamics terhadap kompleks dilakukan pada suhu $300 \mathrm{~K}$ dan waktu simulasi 100 piko detik. Hasil position, velocity dan acceleration disimpan setiap 0,5 piko detik. Parameter lainnya sesuai dengan default pada MOE. Selanjutnya dilakukan analisis hasil dinamik kompleks berdasarkan pada hasil perhitungan simulasi molecular dynamic. Output hasil simulasi berupa database dalam format mdb.

\section{Analisa data}

Dilakukan analisa terhadap ikatan hidrogen dan kontak terhadap residu. Analisa dilakukan melalui ligand interaction pada program MOE. Kemudian pergeseran konformasi posisi hasil simulasi molecular dynamic dilakukan dengan memilih konformasi ligan pada beberapa jangka waktu tertentu hingga akhir simulasi. 


\section{HASIL DAN PEMBAHASAN}

Senyawa yang dijadikan sampel adalah hasil penelitian Khusnah (2018) yaitu senyawa 2, 5, dan 6 berdasarkan nilai afinitas terendah, dengan nilai energi bebas ikatan berturut-turut $-7,2 \mathrm{kcal} / \mathrm{mol},-6,9 \mathrm{kcal} / \mathrm{mol}$, dan $-6,9 \mathrm{kcal} / \mathrm{mol}$. Gefitinib digunakan sebagai kontrol atau pembanding berdasarkan penelitian yang dilakukan oleh Khusnah (2018). Gefitinib termasuk ke dalam golongan obat target yang digunakan pada kanker paru. Secara khusus, agen ini bersaing dengan pengikatan ATP ke domain tirosin kinase EGFR, sehingga menghambat autofosforilasi reseptor dan mengakibatkan penghambatan transduksi sinyal.

Melalui simulasi molecular dynamic terhadap 3 senyawa analog kalkon dan kontrol positif yang telah didocking ini diharapkan dapat menemukan senyawa yang stabil terhadap perubahan termodinamika yang dapat dilihat dari energi konformasi, ikatan hidrogen yang terbentuk dan juga dengan membandingkan kontak residu hasil docking dan simulasi molecular dynamic.

Dari hasil simulasi yang dilakukan diperoleh sebanyak 201 konformasi setiap kompleks yang diperiksa, namun konformasi yang dipilih berdasarkan nilai energi terendah. Konformasi adalah hal penting dalam sistem biomolecular.Konformasimerupakan perubahan koordinat awal atom ke posisi yang baru, kecepatan perpindahan tersebut dapat dihitung dengan satuan waktu, hingga didapatkan konformasi yang stabil (Hans et al, 2008). Konformasi molekul yang stabil dicirikan dengan keadaan energi molekul yang rendah (Arba, 2019).

Selanjutnya, paramater yang diperhitungkan adalah ikatan hidrogen karena pada umumnya interaksi molekuler yang terjadi di dalam tubuh berupa interaksi non kovalen, yaitu interaksi antar atom yang tidak terikat secara kovalen satu sama lain. Ikatan hidrogen merupakan salah satu ikatan non kovalen yang banyak terdapat pada sistem biologis, misalnya protein dan asam nukleat (Siswandono dan Bambang, 2000). Ikatan hidrogen merupakan ikatan utama yang menjaga kestabilan protein sehingga adanya ikatan hidrogen yang terbentuk pada simulasi molecular dynamic ini menandakan kestabilan senyawa tersebut.

Kecocokan asam amino terhadap kontrol positif juga merupakan salah satu parameter dalam studi molecular dynamic ini. Semakin banyak jumlah asam amino yang sama dengan kontrol positif dapat diasumsikan senyawa tersebut memiliki kemampuan inhibisi yang hampir sama atau pun lebih baik dengan kontrol positif.. Selama simulasi berlangsung terjadi perubahan interaksi antara ligan dan reseptor, hal ini dapat menyebabkan residu asam amino yang dihasilkan pada molecular docking dan molecular dynamic berbeda. Semakin banyak asam amino yang sama sebelum dan sesudah molecular dynamic menandakan senyawa tersebut stabil dan tahan terhadap perubahan termodinamika

Berdasarkan hasil analisa simulasi molecular dynamic senyawa 2 memiliki nilai konformasi terendah 4.042,95 yang berada pada posisi pertama sehingga visualisasi konformasi yang dianalisis adalah posisi 1 . Setelah dilakukan visualisasi 2D dapat diketahui senyawa 2 hasil molecular dynamic dibandingkan dengan hasil docking memiliki 1 kesamaan residu asam amino yaitu Leu54, sedangkan kesamaan residu asam amino senyawa 2 terhadap gefitinib sebagai kontrol berjumlah 5 residu asam amino yaitu Asp84, Leu82, Leu54, Ser78, dan Asp80. Ikatan hidrogen hasil simulasi molecular dynamic pada senyawa 2 terbentuk antara atom $\mathrm{N}$ dengan asam amino Phe86 dan dapat dilihat pada Gambar 1.

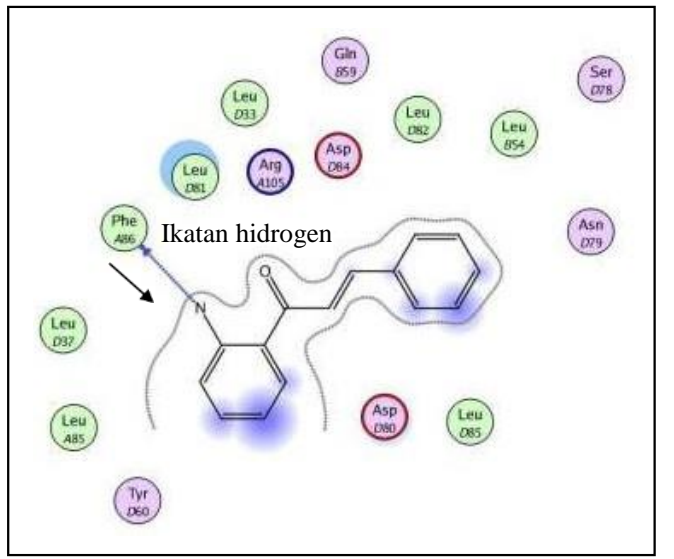

Gambar 1. Interaksi residu protein dengan senyawa 2 secara 2D

Untuk senyawa 5 memiliki nilai konformasi terendah $-4.4050,14$ yang berada pada posisi 1 . Setelah dilakukan visualisasi 2D dapat diketahui senyawa 5 hasil molecular dynamic dibandingkan hasil molecular docking memiliki 6 kesamaan residu asam amino yaitu Leu57, Va193, Leu54, Ile61, Met62 dan Ile99, sedangkan kesamaan residu asam amino senyawa 5 terhadap gefitinib sebagai kontrol berjumlah 4 residu asam amino yaitu; Lys94, Met62, Leu54, van Val93. Banyaknya kesamaan jumlah residu asam amino senyawa dengan residu asam amino kontrol diharapkan memiliki potensi semakin besar sebagai antikanker paru.Ikatan hidrogen yang terbentuk pada inti benzena dengan asam amino Tyr100 dan ikatan hidrogen yang terbentuk antara atom $\mathrm{O}$ dengan asam amino Arg65, dapat dilihat pada Gambar 2.

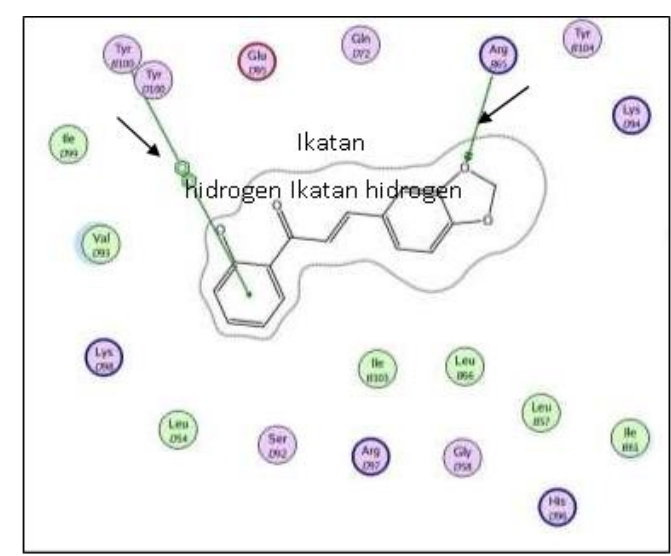

Gambar 2. Interaksi residu protein dengan senyawa 5 secara 2D 
Pada senyawa 6 memiliki nilai konformasi terendah $-4.034,10$ yang berada pada posisi 1. Setelah dilakukan visualisasi 2D dapat diketahui senyawa 6 hasil molecular dynamic dibandingkan hasil molecular docking memiliki 1 kesamaan residu asam amino yaitu Val93, sedangkan kesamaan residu asam amino senyawa 6 terhadap gefitinib sebagai kontrol berjumlah 4 residu asam amino yaitu Leu82, Met62, Val93, Lys94 dapat dilihat pada Gambar 3

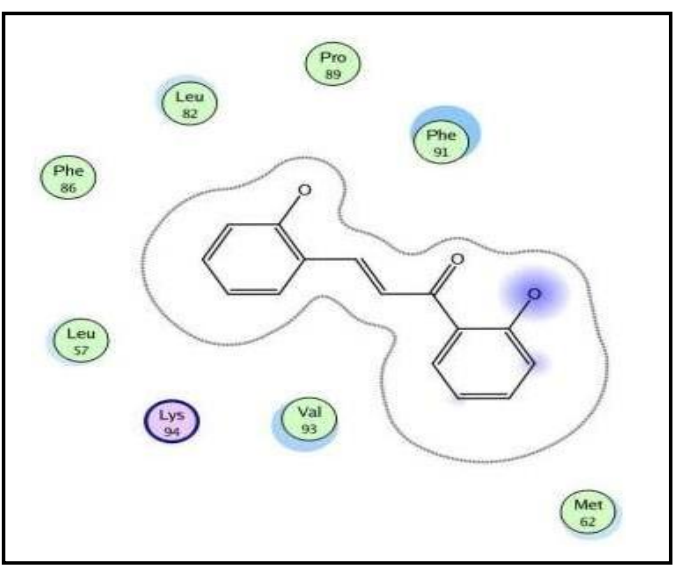

Gambar 3. Interaksi residu protein dengan senyawa 6 secara 2D

Hasil analisa simulasi molecular dynamic gefitinib sebagai kontrol memiliki nilai energi konformasi -2.216,94. Residu asam amino hasil molecular dynamic gefitinib yang sama dengan hasil molecular docking berjumlah 7 yaitu Asn79, Asp80, Met62, Leu54, Val93 dan Ser78 yang juga sama dengan sisi aktif reseptor. Diketahui protein $4 \mathrm{HFZ}$ memiliki sisi aktif His96, Val93, Lys94, His73, Tyr67, Met62, Ile61, Leu57, dan Ile99. Dapat dilihat pada Gambar 4. Protein 4HFZ atau struktur kristalografi dari kompleks peptida MDM2/p53 berfungsi memantau kesehatan sel dan integritas sel DNA, juga bertindak sebagai rem yang kuat untuk menghentikan pembelahan sel sebelum terlalu lambat apabila terjadi kesalahan transkripsi DNA atau gangguan kondisi sel (Corwin, 2009).

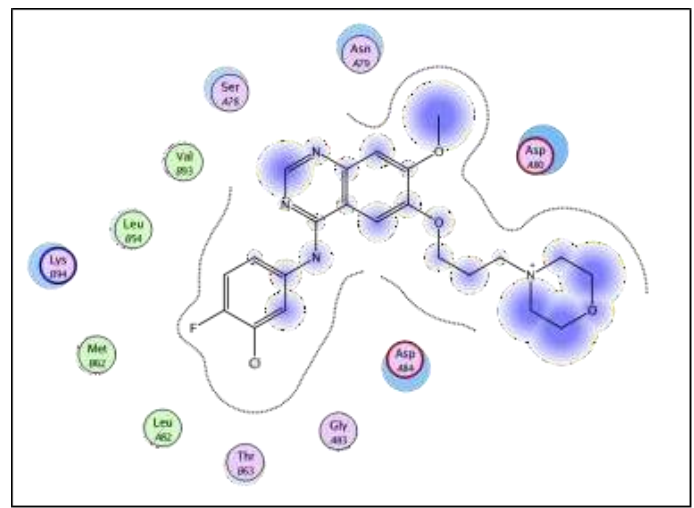

Gambar 4. Interaksi residu protein dengan Gefitinib secara 2D

Berdasarkan analisis dan visualisasi data hasil studi in silico menggunakan molecular dynamic diketahui bahwa senyawa 5 memiliki potensi sebagai inhibitor sel kanker paru-paru A549 karena memiliki ikatan hidrogen sebelum dan sesudah dilakukannya molecular dynamic. Ikatan hidrogen didefinisikan sebagai gaya intermolekul atau intramolekul yang terjadi antara atom yang memiliki keelektronegatifan tinggi dengan atom hidrogen, dan juga merupakan ikatan utama yang menjaga kestabilan protein (Yuwono,2011) .Senyawa $\mathbf{5}$ juga memiliki jumlah kecocokan asam amino hasil molecular dynamic dan molecular docking yang paling banyak diantara senyawa $\mathbf{2}$ dan senyawa $\mathbf{6}$ yang artinya ikatan ligan- reseptor stabil terhadap perubahan termodinamika. Senyawa $\mathbf{5}$ memiliki nilai konformasiyang paling rendah diantara senyawa 2 dan senyawa 6 yang menandakan senyawa tersebut lebih stabil dibanding senyawa lainnya.

Tabel 2. Perbedaan Residu Asam Amino Hasil Docking dan Simulasi Molecular Dynamic

\begin{tabular}{|c|c|c|c|}
\hline Senyawa & Docking & $M D$ & $\begin{array}{c}\text { Jumlah } \\
\text { kecocok } \\
\text { an Asam } \\
\text { Amino } \\
\end{array}$ \\
\hline 2 & $\begin{array}{l}\text { Leu54,Ile99, } \\
\text { Met62,Val93 } \\
\text { dan Ile61 }\end{array}$ & $\begin{array}{l}\text { Tyr60,Leu85, } \\
\text { Leu37,Phe86, } \\
\text { Leu81,Leu33, } \\
\text { Gln59,Arg10 } \\
\text { 5,Asp84,Leu8 } \\
\text { 2,Leu54,Ser7 } \\
\text { 8,Asn79, } \\
\text { Leu85,Asp80 }\end{array}$ & 1 \\
\hline 5 & $\begin{array}{l}\text { Leu57, } \\
\text { Leu54, }\end{array}$ & $\begin{array}{l}\text { Tyr100,Glu } \\
\text { 95,Gln72,Ar } \\
\text { g65,Tyr104, } \\
\text { Lys94,Met6 } \\
\text { 2,Tyr67,Asp } \\
\text { 68,Ile61,Le } \\
\text { u57,Leu56,I } \\
\text { le103,His96, } \\
\text { Gly58,Arg9 } \\
\text { 7,Ser92,Leu } \\
\mathbf{5 4 , \quad L y s 9 8 ,} \\
\text { Val93,Ile99 } \\
\end{array}$ & 6 \\
\hline 6 & $\begin{array}{l}\text { Ile99,Val93, } \\
\text { Ile61, dan } \\
\text { Leu54 }\end{array}$ & $\begin{array}{l}\text { Phe86,Leu82, } \\
\text { Pro89,Phe91, } \\
\text { Met62,Val93, } \\
\text { Lys94,Leu57 }\end{array}$ & 1 \\
\hline Gefitinib & $\begin{array}{l}\text { Gly58,Asn79,I } \\
\text { eu54,Ser78,As } \\
\text { p84,Leu81,Asp } \\
\text { 80,Met62,Gln7 } \\
\text { 2,Tyr67,Val93, } \\
\text { Val75, } \\
\text { Ile61,Leu57 }\end{array}$ & $\begin{array}{l}\text { Asn79,Asp80 } \\
\text {,Asp84,Gly83 } \\
\text {,Thr63,Leu82 } \\
\text {,Met62,Lys9 } \\
\text { 4,Leu54, } \\
\text { Val93, Ser78 }\end{array}$ & 7 \\
\hline
\end{tabular}

Keterangan: Huruf cetak tebal menunjukkan kesamaan asam amino hasil docking dan molecular dynamic.

Berdasarkan hal tersebut dapat diasumsikan bahwa senyawa 5 memiliki potensi sebagai antikanker paru-paru, sehingga perlu dilakukan penelitian lanjutan 
Tabel 3. Hasil Molecular Dynamic dan Docking dari kompleks dan Kontrol Positif

\begin{tabular}{cccccc}
\hline \multirow{2}{*}{ Senyawa } & \multicolumn{5}{c}{ Parameter } \\
\cline { 2 - 6 } & \multicolumn{2}{c}{ Molecular Docking } & \multicolumn{2}{c}{ Molecular Dynamic } \\
\cline { 2 - 5 } & $\begin{array}{c}\text { Energi Bebas } \\
\text { Ikatan } \\
\text { (kcal/mo l) }\end{array}$ & $\begin{array}{c}\text { Ikatan } \\
\text { Hidrogen }\end{array}$ & $\begin{array}{c}\text { Energi } \\
\text { Konformasi }\end{array}$ & Ikatan Hidrogen & $\begin{array}{c}\text { Jumlah kecocokan } \\
\text { Asam Amino terhadap } \\
\text { Gefitinib }\end{array}$ \\
\hline 2 & -7.2 & Terbentuk & $-4.042,95$ & Terbentuk & 5 \\
5 & -6.9 & Terbentuk & $-4.050,14$ & Terbentuk & 4 \\
6 & -6.9 & Terbentuk & $-4.034,10$ & Tidak Terbentuk & 4 \\
Gefitinib & -8.4 & Tidak & $-2.216,95$ & Tidak Terbentuk & - \\
& & Terbentuk & & & \\
\hline
\end{tabular}

seperti pharmacophore dan 3D QSAR untuk memastikan aktivitas dan stabilitas senyawa. Sedangkan senyawa 2 dan senyawa $\mathbf{6}$ dikatakan tidak stabil karena tidak memenuhi parameter yang telah ditentukan yaitu nilai energi konformasi, ikatan hidrogen, jumlah kecocokan asam amino terhadap gefitinib, jumlah kecocokan asam amino hasil molecular docking dan molecular dynamic, dapat dilihat pada Tabel 2 dan Tabel 3

\section{KESIMPULAN}

Berdasarkan dari hasil penelitian yang telah dilakukan, maka dapat disimpulkan bahwa aktivitas senyawa analog kalkon senyawa 5 diasumsikan mampu berikatan dengan reseptor dan stabil karena memiliki nilai energi konformasi yang rendah, membentuk dua ikatan hidrogen dengan sisi aktif reseptor yaitu Arg65 dan Tyr100, memiliki banyak kesamaan asam amino dengan kontrol positif yaitu gefitinib serta memiliki lebih banyak kesamaan asam amino hasil molecular docking dibanding dengan 2 senyawa lainya.

\section{DAFTAR PUSTAKA}

Anonim. 2015. Situasi Penyakit Kanker. Departemen. Kesehatan Republik Indonesia. Jakarta.

$\begin{array}{cl}\text { Anonim. 2017. } & \text { Pedoman } \\ \text { Pelayanan. } & \text { Kedokteran Kanker Paru. } \\ \text { Kementrian } & \text { Kesehatan Republik Indonesia. } \\ \text { Jakarta. } & \end{array}$

Arba, M. 2019. Farmasi Komputasi. Yogyakarta : Deepublish

Corwin, J. E. 2009. Buku Saku Patofisiologi edisi 3. Buku Kedokteran ECG : Jakarta.

Dipiro, J., Talbert, R., Yee, G., Matzke, G., Wells, B. and Posey, M., 2008, Pharmacotherapy: A Pathophysiologic Approach, Seventh Edition, The MC Graw Hill, New York.
Hans, D.H., Gerd, F., Raimud, M., Hugo, K., Hendrik, T., 2008. Molecular Modelling: Basic Principles and Applications. Volume 5. New York . John Wiley \& Sons.

Jusuf, A., A. Wibawanto, A. Icksan, E. Syahrudddin, Juniarti, dan S. Endardjo. 2015. Kanker Paru Jenis Karsinoma Bukan Sel Kecil Pedoman NasionalUntuk Diagnosa \& Penatalaksanaan di Indonesia.PDPI. Jakarta.

Khusnah, A. 2018. Studi In Silico Senyawa Analog Kalkon sebagai Inhibitor untuk sel Kanker ParuParu A549. Skripsi. Pekanbaru : Sekolah Tinggi Ilmu Farmasi Riau

Klamerus, J.F., Julie, R.B and David, S. E. 2012. Patients' Guide to Lung Cancer (Buku Panduan untuk Penderita Kanker Paru).Penerjemah: dr. Melviawati. Jakarta: Indeks

Pingaew, R. Saekee, A. Mandi, P. Nantasenamat, C. Prachayasitikul, S. Ruchirawat, S and Prachayasitikul, V. 2014. Synthesis, Biological Evaluation and Molecular Docking of Novel Chalcone-Coumarin Hybrid as Anticancer and Antimalarial. Europe Journal Medicinal Chemistry. 85(5): 65-76.

Siswandono dan Bambang, S. 2000. Kimia Medisinal. Surabaya: Airlangga University Press.

Yuwono, T. 2011. Biologi Molekuler Edisi V. Yogyakarta: Penerbit Erlangga. 